\title{
Morbidity study of extruder personnel with potential exposure to brominated dioxins and furans. I Results of blood monitoring and immunological tests
}

\author{
M A Zober, M G Ott, O Päpke, K Senft, C Germann
}

\begin{abstract}
The potential for exposure of employees to polybrominated dibenzofurans (PBDFs) and dibenzo-p-dioxins (PBDDs) during extrusion blending of resins containing decabromodiphenyl ether was established through previous air monitoring (area samples) and biomonitoring studies. The findings presented herein are further biomonitoring results for 42 employees and immunological tests for exposed and referent employees. Among potentially exposed men, 2,3,7,8-TBDF and 2,3,7,8-TBDD concentrations in blood lipid ranged from non-detectable to 112 parts per trillion (ppt) and from non-detectable to 478 ppt respectively. Biomonitoring results correlated well with assignments in the extruder work area when adjusted for process changes and engineering improvements and provided biological half life estimates of between $1 \cdot 1$ and 1.9 years for 2,3,7,8-TBDF and between 2.9 and 10.8 years for $2,3,7,8-T B D D$. Results for 16 measures of the immune system were examined in relation to exposure (exposed $v$ referent group) and in relation to the biomonitoring data. Some individual trends in immunological parameters with exposure and covariates such as age and cigarette smoking were found (for example, an increase in complement $\mathrm{C4}$ with increasing concentrations of PBDFs and PBDDs, increased lymphocyte subpopulation counts with cigarette smoking); however, the overall
\end{abstract}

Occupational Medical and Health Protection Department, BASF Aktiengesellschaft, Ludwigshafen, Germany

M A Zober, K Senft, C Germann

Corporate Medical Department, BASF Corporation, Parsippany, New Jersey, USA

M G Ott

Ergo Forschungsgesellschaft GmbH, Hamburg, Germany

O Päpke clinical assessment was that the immune system of exposed employees was not adversely impacted at these burdens of PBDFs and PBDDs.

An air sampling programme was initiated in 1988 at BASF AG to determine if polybrominated dibenzofurans (PBDFs) and dibenzo-p-dioxins (PBDDs) were being formed during extrusion blending of polybutyleneterephthalate (PBTP) with decabromodiphenyl ether. The analytical results showed that both PBDF and PBDD congeners were present in samples taken from near the extruder head and in general workroom air during production runs. ${ }^{1}$

In a follow up to the air monitoring results, a preliminary health examination study of 10 potentially exposed and 10 referent employees was undertaken in 1989. Blood samples from a subgroup of five employees who worked for many years in the extrusion operations and five referents were collected and analysed for PBDFs and PBDDs. The analytical results for the five PBTP production employees were all positive for PBDFs and PBDDs. More specifically, 2,3,7,8-TBDD was detected at concentrations of 100 to 500 parts per trillion (ppt) and 2,3,7,8TBDF at concentrations of 100 to $200 \mathrm{ppt}$ respectively. Among the referents, PBDFs and PBDDs were either not detected or were marginally present. The initial medical examinations did not identify any notable differences in health parameters between the exposed and referent groups.

These findings were reported to employees and governmental authorities and have been summarised in a published government report on the use of polybrominated diphenyl ethers (PBDEs) as flame retardants. $^{2}$ As a precautionary measure BASF stopped using PBDEs in resin production and initiated a comprehensive medical examination programme to assess possible health effects among employees with past exposures to these materials. In this paper, the results of blood monitoring to determine internal exposure and immunological findings are presented. 


\section{Subjects and methods \\ SUBJECTS}

For this investigation the study group consisted of 34 PBTP production plant employees and eight technical support $(R+D)$ personnel who were potentially exposed to PBDFs and PBDDs during production of resins containing PBDEs. Eligible employees were identified by plant management using 1989 year end census lists of active departmental employees. Emphasis was placed on selecting personnel who were specifically assigned to extrusion operations. Only one of 43 employees who had been asked chose not to participate in the voluntary medical examination programme. The 42 study participants consisted of 29 extrusion process operators, including the five who had taken part in the earlier biomonitoring study, three maintenance mechanics assigned to the production plant, two production employees assigned to other areas of the production facility (mixing and packaging), and eight personnel who provided $R+D$ support for the extrusion operations. The process operators had spent from 40 to 100 per cent of their work hours in the extruder operations and had started their work in the PBTP plant between 1967 and 1988.

A group of 42 referents was recruited from a similar resin production plant with comparable technical support activities but no use of PBDEs within the plant. Referents were frequency matched to the study group by age, sex, general type of employment (production $v$ technical support) and nationality using plant census data. There were no women employees in either group.

\section{METHODS}

\section{Exposure assessment}

Although PBTP production operations predated the 1970s; brominated flame retardants were not used in the plant before 1975 and octa and decabromodiphenyl ethers were probably not processed before 1977. As previously indicated, all PBDE use was ended in late 1989 . Since 1990 only non-ether based brominated flame retardants have been used in the facility. Air monitoring results from July 1990 identified only trace amounts of PBDF and PBDD congeners and no $2,3,7,8-T B D F$ or $2,3,7,8-T B D D$ using an improved sampling method that enabled detection at lower limits than was previously possible (unpublished results, BASF AG, 1991-For sampling method see "Verfahren zur Bestimmung von 2,3,7,8-TCDD und anderen in 2,3,7,8-Stellung chlorierten PCDDs und PCDFs", . Hauptverband der gewerblichen Berufsgenossenschaften, $5205 \mathrm{St}$ Augustin 2, Alte Heerstraße 111, publ no ZHI/ 120.47 Jan 1991, Carl Heymanns Verlag, Luxemburger Str 449, 5000 Köln 41). The results for total tetra-BDFs and tetra-BDDs were 250 and 700 times less respectively than air samples obtained at the same location in 1988.

The extrusion operations were located apart from the mixing and packaging operations on a separate level of the production facility. The extrusion work area contained a series of extruders set up to produce various related products. Only a portion of the unit's production capacity was assigned to the manufacture of resins containing flame retardants. Over the years, changes took place in both resin recipes and product mix that complicate the assessment of past exposures. The use of octa and decabromodiphenyl ethers steadily increased during the early $1980 \mathrm{~s}$, peaked in 1985-6, and then declined until the end of 1989 when their use was stopped. During this time process changes occurred that may have reduced the likelihood of exposure of employees. Changes mostly completed up to the end of 1986 included modifying the procedure for feeding process materials into the extruders and improving the dust exhaust at the extruder feed inlet. More recent process changes since 1990 include further improvements in ventilation, the use of an encapsulated metered feeder, and, as mentioned, the replacement of PBDEs with other materials.

The duration of potential exposure to PBDFs and PBDDs from PBDEs was calculated based on job assignment records and estimates of the per cent of time each operator was actually assigned to the extruder work area. The computational algorithm was simply to multiply the employment duration as a process operator (expressed in years) by the fraction of time spent in the extrusion work area. For the 13 employees not routinely assigned to these operations, duration of exposure could not be reliably assessed.

The principal route of exposure of employees is not known. It was known that PBDFs and PBDDs were detectable in both air samples and blood specimens. Because of the relative stability and lipid solubility of these molecules, however, it was thought that blood concentrations should provide a reasonable index of past cumulative exposure, particularly for the more stable molecules such as $2,3,7,8-T B D D$.

\section{Biological samples}

Blood specimens for the present study were collected between February and April 1990. Up to $200 \mathrm{ml}$ of venous blood was drawn from participants after an overnight fast. The samples were subdivided and used for various analytical studies. Blood samples for PBDF and PBDD determinations were again collected in mid-1991 for five of the subjects who had participated in the previous pilot study. Thus for these subjects three specimens each were available for PBDF and PBDD analyses over a three year period. No PBDF or PBDD analyses were performed for referents in the present study. 
Determination of PBDFs and PBDDs

Venous blood $(100 \mathrm{ml})$ was collected in specially prepared test tubes containing anticoagulant provided by ERGO-Forschungsgesellschaft Hamburg, Germany. The blood specimens were deep frozen and transported by express to the ERGO laboratory in Hamburg for analysis. The laboratory, which successfully participated in the 1990 WHO $\mathrm{PCDD} / \mathrm{F}$ interlaboratory blood study, was blinded to exposure state for the pilot medical study and to duration of potential exposure in the present study. The PBDFs and PBDDs were determined from $40 \mathrm{~g}$ of whole blood spiked with commercially available ${ }^{13} \mathrm{C}$-labelled brominated dioxin and furan internal quantification standards. ${ }^{34}$ The measurements were performed by gas chromatography/mass spectroscopy on DB 5 fused silica columns using the VG 7035 system at a mass resolution of 1.500 (LRMS) for 1989 samples and the VG AutoSpec system at a mass resolution of 10.000 (HRMS) for 1990 and 1991 samples. Injection was "on-column" in 1989 and 1991 and "splitless" in 1990. The PBDF and PBDD concentrations were expressed in $\mathrm{pg} / \mathrm{g}$ (ppt) based on the lipid content of the blood. In the text tables and analyses, results are presented separately for $2,3,7,8-$ TBDF and 2,3,7,8-TBDD. Toxicity equivalents (TEQs) were calculated as well to express the PBDF and PBDD congener profiles as a single number, however, using factors derived for chlorinated dioxins and furans. Two sets of TEQ factors were used in the calculations, those of the German Federal Office of Health, Bundesgesundheitsamt (BGA) and of Safe. ${ }^{56}$

\section{Immunological investigations}

Immunological tests were performed on the day of specimen collection. Tests for serum $\gamma$-globulin, $\operatorname{IgA}, \operatorname{IgG}, \operatorname{IgM}$, and IgE were performed by the clinical laboratory of the Occupational Medical and Health Protection Department of BASF AG; all other tests were performed by another laboratory (Professor Seelig and Partners, Karlsruhe, Germany). Serum $\gamma$-globulin concentration was assessed by densitometry after separation using an Elphor-Fraktomat (Bender and Holbein, München, Germany). Serum IgA, IgG and IgM concentrations were determined using an immunoturbidimetric test on the BM/Hitachi System (Boehringer, Mannheim, Germany). An enzyme immunoassay for IgE was performed on an ES 300 (Boehringer, Mannheim, Germany). Circulating immune complexes were measured by precipitation with the Raji cell assay. The presence or absence of antinuclear antibodies (ANAs) was determined by indirect immunofluorescence using rat stomach, kidney, and liver as substrate. Complement $\mathrm{C} 3$ and $\mathrm{C} 4$ concentrations were determined by nephelometric measurement on a Behring-Nephelometer (Behring, Marburg, Germany).

Analyses of lymphocyte subsets were performed with heparinised venous blood. The lymphocyte surface markers were analysed by flow cytometry (FACScan, Becton Dickinson, Heidelberg, Germany) using monoclonal antibodies (MABs). The MABs were obtained from Coulter Electronics (Krefeld, Germany) and Becton Dickinson (Heidelberg, Germany). The following MABs were used: CD3 for T-cells, CD4 for T-helper cells, CD8 for T-suppressor cells, CD4 CDW29 for T-helper/ inducer cells, CD11 for natural killer (NK) cells and monocytes, and CD19 for B-cells. The helperinducer subset of CD4 CDW29 was enumerated using an antibody mixture containing one fluoresceinisothiocyanate (FITC) labelled and one phycoerythrine $^{\circledR}$ (PE) labelled MAB.

\section{Statistical methods}

As well as overall summary comparisons by job and date of first exposure, the biomonitoring results were examined in more detail for a subgroup of 29 production employees assigned to the extruder operations. In these analyses blood concentrations of 2,3,7,8-TBDF and 2,3,7,8-TBDD were correlated with the cumulative duration of time spent in the extruder work area during each of seven two year calendar periods. These analyses were undertaken to determine which exposure conditions may have been most important in explaining variability in the biomonitoring results. For five employees with repeat blood determinations of PBDF and PBDD concentrations, elimination rates were estimated using regression analyses.

The relations between immunological parameters and exposure were investigated in several ways. Initially, direct $t$ test comparisons were made between the referent group and a subset of 21 study group members with combined 2,3,7,8-TBDF and $2,3,7,8$-TBDD concentrations above 20 ppt. These 21 subjects comprised 17 of the 29 extruder operators plus the three maintenance mechanics and one other production employee. These analyses were supplemented by regression analyses that included all 84 study participants and assumed the referents to have non-detectable exposures to brominated dibenzofurans and dibenzo-p-dioxins. The regression analyses were undertaken to identify other important predictors of the various parameters of immune state and to determine if significant correlations existed between immunological parameters and the biomonitoring results with inclusion of important covariates. The four covariates investigated were age, cigarette smoking, alcohol intake, and body mass index. Cigarette smoking was coded as the current number of cigarettes smoked per day. Alcohol intake was calculated from questionnaire responses on 

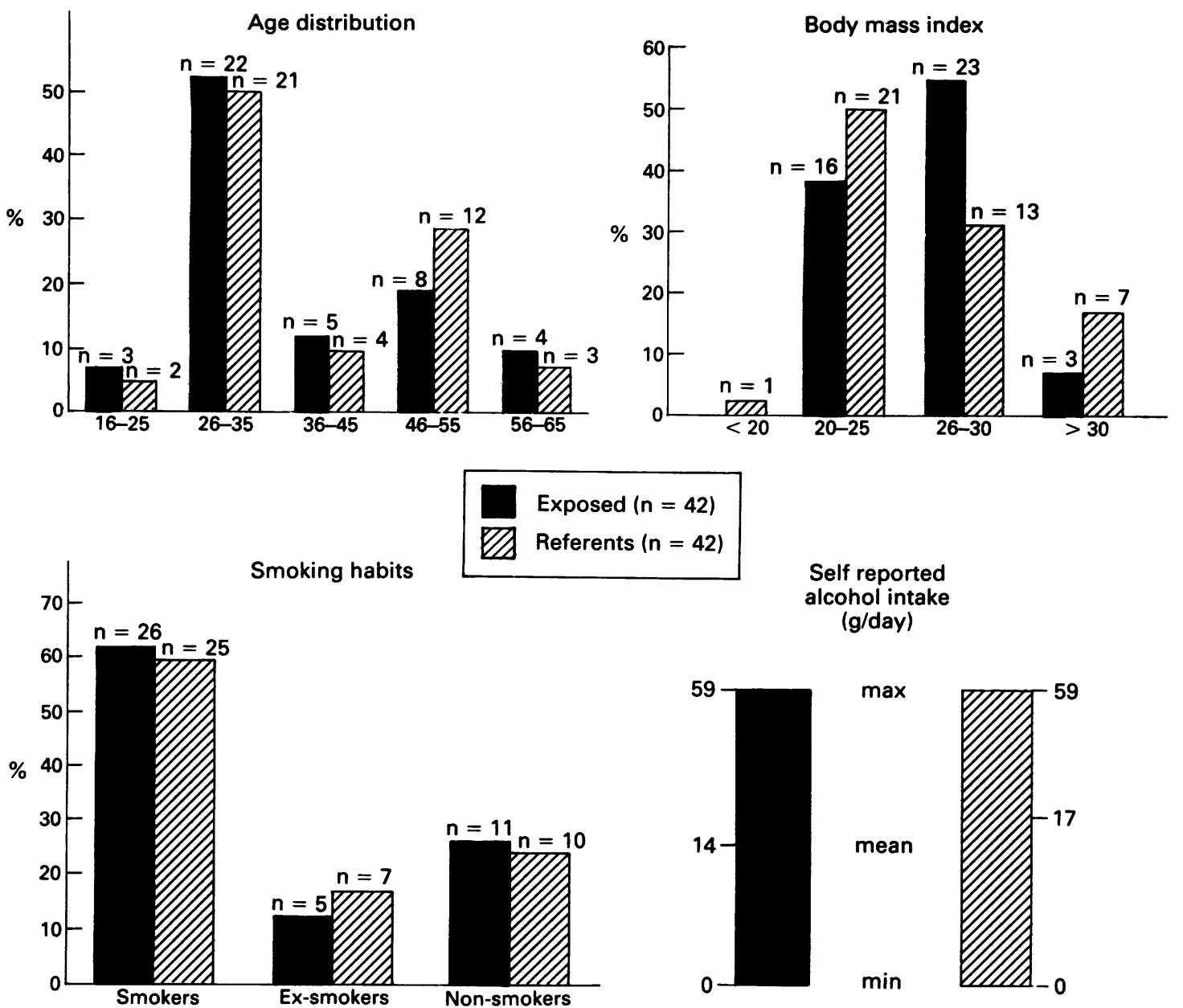

Figure 1 Anthropometric data, smoking and drinking habits of exposed persons and referents.

wine, beer, and liquor consumption using a computational algorithm provided by Giovannucci et al. ${ }^{7}$

Basic descriptive analyses and simple $t$ tests were performed with the Research System RS/1 statistical package (BBN Software Products Corp, Cambridge, MA). The Proc Regression procedure from Version 6.03 of the Statistical Analysis System (SAS) was used in the regression analyses.

\section{Results}

Figure 1 shows the age, smoking, self reported alcohol intake, and body mass index contrasts between the study group and referents. No remarkable differences were found between the two groups in any of these measures. The average age of study group participants was 36.6 years and that of the referents, 38.3 years. The average number of cigarettes smoked daily per person was 11.4 and 11.5 for the study group and referents respectively. Within the study group weak positive correlations ( $p>0.05)$ existed between the biomonitoring measures and both age and smoking. Alcohol intake and body mass index were unrelated to the biomonitoring measures.

BIOMONITORING RESULTS

Table 1 summarises the biomonitoring results by job type and first year of possible exposure to PBDEs. By job type, the lowest internal exposures were seen for the $R+D$ personnel. Except for one subject in this group, 2,3,7,8-TBDD exposures were non-detectable. The maximum concentration of $2,3,7,8-T B D F$ in the group was $11 \mathrm{ppt}$ and the maximum toxicity 
Table 1 Summary of internal exposure data by job type and first year on job with possible exposure to PBDEs

\begin{tabular}{|c|c|c|c|c|c|c|c|c|c|c|c|c|c|}
\hline \multirow[b]{2}{*}{ Job type and first year on job } & \multirow[b]{2}{*}{ No } & \multicolumn{3}{|c|}{ 2,3,7,8 TBDF (ppt) } & \multicolumn{3}{|c|}{ 2,3,7,8 TBDD (ppt) } & \multicolumn{3}{|c|}{$T E Q-B G A(p p t)$} & \multicolumn{3}{|c|}{$T E Q-S A F E(p p t)$} \\
\hline & & Median & Min & $\operatorname{Max}$ & Median & Min & Max & Median & Min & Max & Median & Min & $\operatorname{Max}$ \\
\hline $\begin{array}{l}\text { Extruder operators } \\
1975-85 \\
1986-88\end{array}$ & $\begin{array}{l}29 \\
18 \\
11\end{array}$ & $\begin{array}{r}8 \\
18 \\
4\end{array}$ & $\begin{array}{l}\text { ND } \\
\text { ND } \\
\text { ND }\end{array}$ & $\begin{array}{r}112 \\
112 \\
11\end{array}$ & $\begin{array}{l}40 \\
91 \\
\text { ND }\end{array}$ & $\begin{array}{l}\text { ND } \\
16 \\
\text { ND }\end{array}$ & $\begin{array}{r}478 \\
478 \\
11\end{array}$ & $\begin{array}{c}61 \\
116 \\
3\end{array}$ & $\begin{array}{l}\text { ND } \\
16 \\
\text { ND }\end{array}$ & $\begin{array}{r}564 \\
564 \\
26\end{array}$ & $\begin{array}{r}83 \\
175 \\
6\end{array}$ & $\begin{array}{l}\text { ND } \\
16 \\
\text { ND }\end{array}$ & $\begin{array}{r}848 \\
848 \\
37\end{array}$ \\
\hline Maintenance mechanics (1975-83) & 3 & 16 & $<7$ & 26 & 17 & 17 & 22 & 27 & 21 & 34 & 45 & 29 & 53 \\
\hline $\begin{array}{l}\text { Production employees; } \\
\text { other areas (1976-82) }\end{array}$ & 2 & 7 & 7 & 7 & 28 & 7 & 48 & 37 & 10 & 64 & 61 & 17 & 104 \\
\hline $\mathbf{R}+\mathbf{D}$ personnel & 8 & 2 & ND & 11 & ND & ND & 5 & 0 & ND & 9 & 0 & ND & 17 \\
\hline
\end{tabular}

ND $=$ not detectable.

equivalent scores were below 20 units for both measures.

Highest median internal exposures were found for the 18 extruder operators who had been first employed in that capacity before 1986 . For the 11 operators first assigned to the unit during or after 1986, internal exposures were comparable with those seen for the R + D personnel, and for the seven persons employed after 1986, 2,3,7,8-TBDD levels were all non-detectable. Exposures were intermediate for five other long term employees of the PBTP unit, who had not worked as extruder operators.

The four exposure measures were highly correlated with one another as would be expected. Because the 2,3,7,8-TBDD concentration is weighted so heavily in the calculation of both toxicity equivalent measures, however, the correlation coefficients among these three measures even exceeded 0.99 . Consequently, regression analyses of parameters of the immune system on exposure measures are reported only for 2,3,7,8-TBDD and 2,3,7,8-TBDF.

Further correlation analyses for the subgroup of 29 extruder operators explored the relations between duration of exposure (cumulative time spent in the extruder work area) and the internal exposure measures. Duration of exposure was calculated in total and separately for two year intervals beginning in 1975. Highest correlation coefficients were found for the three two year periods $1981-2,1983-4$, and 1985-6. For these intervals, the correlation coefficients ranged from 0.64 to 0.66 for $2,3,7,8$-TBDF and from 0.53 to 0.65 for $2,3,7,8-T B D D$. Durations of exposure during 1975-6 were unrelated to either $2,3,7,8$-TBDF or $2,3,7,8-$ TBDD concentration.

\section{IMMUNE SYSTEM PARAMETERS}

Table 2 presents the summary statistics on 16 measures of the immune system (expressed as 23 different statistical variables) for the 21 employees with combined 2,3,7,8-TBDF and 2,3,7,8-TBDD

Table 2 Summary of immunological data

\begin{tabular}{|c|c|c|c|c|c|c|c|c|c|}
\hline & \multicolumn{4}{|c|}{ Exposed $(n=21)$} & \multicolumn{4}{|c|}{ Referents $(n=42)$} & \multirow[b]{2}{*}{ p Value } \\
\hline & Mean & $S D$ & Min & $\operatorname{Max}$ & Mean & $S D$ & Min & $\operatorname{Max}$ & \\
\hline & \multicolumn{9}{|c|}{ Immunocompetent cells } \\
\hline \multirow[t]{2}{*}{ 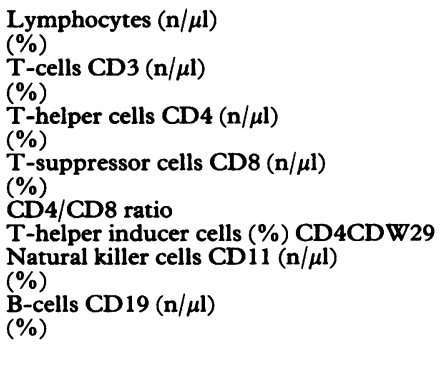 } & $\begin{array}{c}2179 \cdot 5 \\
33 \cdot 4 \\
1600 \\
73 \cdot 6 \\
973 \cdot 3 \\
44 \cdot 8 \\
665 \\
30 \cdot 8 \\
1 \cdot 6 \\
26 \cdot 0 \\
280 \cdot 5 \\
12 \cdot 7 \\
276 \cdot 3 \\
12 \cdot 5\end{array}$ & $\begin{array}{r}678 \\
8 \cdot 4 \\
494 \cdot 6 \\
6 \cdot 7 \\
318 \cdot 9 \\
6 \cdot 1 \\
282 \cdot 6 \\
7 \cdot 9 \\
0 \cdot 5 \\
7 \cdot 1 \\
175 \cdot 2 \\
6 \cdot 8 \\
156 \cdot 0 \\
4 \cdot 4\end{array}$ & $\begin{array}{r}920 \\
18 \\
700 \\
58 \\
330 \\
31 \\
310 \\
18 \\
0 \cdot 8 \\
15 \\
20 \\
2 \\
53 \\
2\end{array}$ & $\begin{array}{r}3550 \\
49 \\
2550 \\
84 \\
1640 \\
55 \\
1540 \\
46 \\
2 \cdot 8 \\
37 \\
789 \\
30 \\
760 \\
24\end{array}$ & $\begin{array}{c}2267 \cdot 6 \\
36 \\
1672 \cdot 6 \\
73 \cdot 3 \\
1032 \\
45 \cdot 1 \\
717 \cdot 2 \\
32 \cdot 0 \\
1 \cdot 5 \\
23 \cdot 2 \\
250 \cdot 8 \\
11 \cdot 9 \\
286 \cdot 4 \\
12 \cdot 3\end{array}$ & $\begin{array}{r}837 \cdot 5 \\
12 \cdot 4 \\
668 \\
7 \cdot 7 \\
444 \cdot 6 \\
8 \cdot 9 \\
282 \cdot 4 \\
7 \cdot 1 \\
0 \cdot 6 \\
7 \cdot 1 \\
149 \cdot 9 \\
7 \cdot 1 \\
199 \cdot 3 \\
5 \cdot 1\end{array}$ & $\begin{array}{c}1160 \\
14 \\
630 \\
54 \\
320 \\
28 \\
310 \\
18 \\
0 \cdot 6 \\
13 \\
10 \\
1 \\
90 \\
6\end{array}$ & $\begin{array}{r}4660 \\
67 \\
3450 \\
86 \\
2100 \\
60 \\
1580 \\
51 \\
2 \cdot 7 \\
39 \\
720 \\
29 \\
1280 \\
30\end{array}$ & $\begin{array}{l}0.7 \\
0.4 \\
0.7 \\
0.9 \\
0.6 \\
0.9 \\
0.5 \\
0.5 \\
0.7 \\
0.1 \\
0.5 \\
0.7 \\
0.8 \\
0.9\end{array}$ \\
\hline & \multicolumn{9}{|c|}{ Humoral parameter } \\
\hline $\begin{array}{l}\gamma \text {-Globulin }(\%) \\
\text { IgA (mg/dl) } \\
\text { IgG (mg/dl) } \\
\text { IgM (mg/dl) } \\
\text { IgE (IU/ml) } \\
\text { Immune complexes }(\mu \mathrm{g} / \mathrm{ml}) \\
\text { Complement C3 (mg/dl) } \\
\text { Complement C4 (mg/dl) } \\
\text { Antinuclear antibodies }(\% \text { positive) }\end{array}$ & $\begin{array}{r}13 \cdot 4 \\
246 \cdot 0 \\
1057 \cdot 7 \\
142 \cdot 0 \\
201 \cdot 5 \\
3 \cdot 9 \\
83 \cdot 5 \\
31 \cdot 1 \\
42 \cdot 9\end{array}$ & $\begin{array}{r}2 \cdot 6 \\
102 \cdot 6 \\
199 \cdot 0 \\
52 \cdot 6 \\
261 \cdot 2 \\
2 \cdot 5 \\
15 \cdot 2 \\
9 \cdot 2\end{array}$ & $\begin{array}{c}9 \cdot 1 \\
74 \\
681 \\
73 \\
0 \\
2 \cdot 5 \\
59 \cdot 5 \\
19\end{array}$ & $\begin{array}{c}17 \cdot 6 \\
455 \\
1328 \\
246 \\
850 \\
13 \cdot 3 \\
107 \\
53 \cdot 6\end{array}$ & $\begin{array}{c}14 \cdot 1 \\
245 \\
1102 \cdot 9 \\
114 \cdot 7 \\
188 \cdot 5 \\
9 \\
77 \cdot 8 \\
28 \cdot 5 \\
31 \cdot 0\end{array}$ & $\begin{array}{r}2 \cdot 4 \\
106 \cdot 8 \\
207 \cdot 1 \\
46 \cdot 5 \\
421 \\
18 \cdot 2 \\
11 \cdot 2 \\
8 \cdot 9\end{array}$ & $\begin{array}{c}8 \cdot 3 \\
69 \\
764 \\
26 \\
0 \\
2 \cdot 5 \\
56 \cdot 6 \\
13 \cdot 9\end{array}$ & $\begin{array}{c}20 \cdot 9 \\
519 \\
1526 \\
224 \\
2523 \\
106 \cdot 4 \\
97 \cdot 5 \\
51 \cdot 3\end{array}$ & $\begin{array}{l}0.3 \\
0.9 \\
0.4 \\
0.04 \\
0.9 \\
0.2 \\
0.1 \\
0.3 \\
0.3\end{array}$ \\
\hline
\end{tabular}




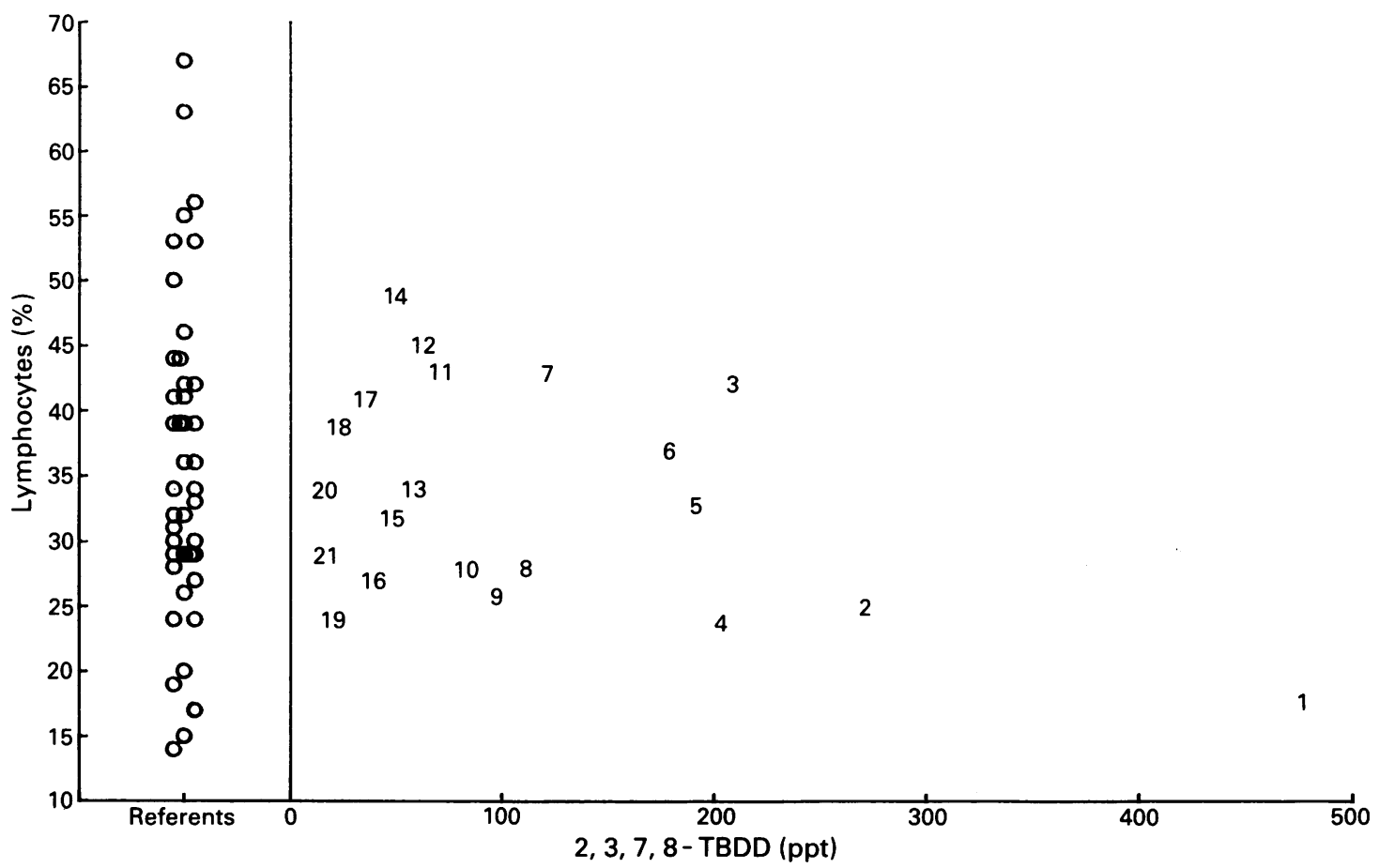

Figure 2 Lymphocytes (\%) $v$ 2,3,7,8-TBDD (ppt) based on the fat content of blood of 21 exposed persons with combined 2,3,7,8-TBDF and 2,3,7,8-TBDD concentrations above 20 ppt.

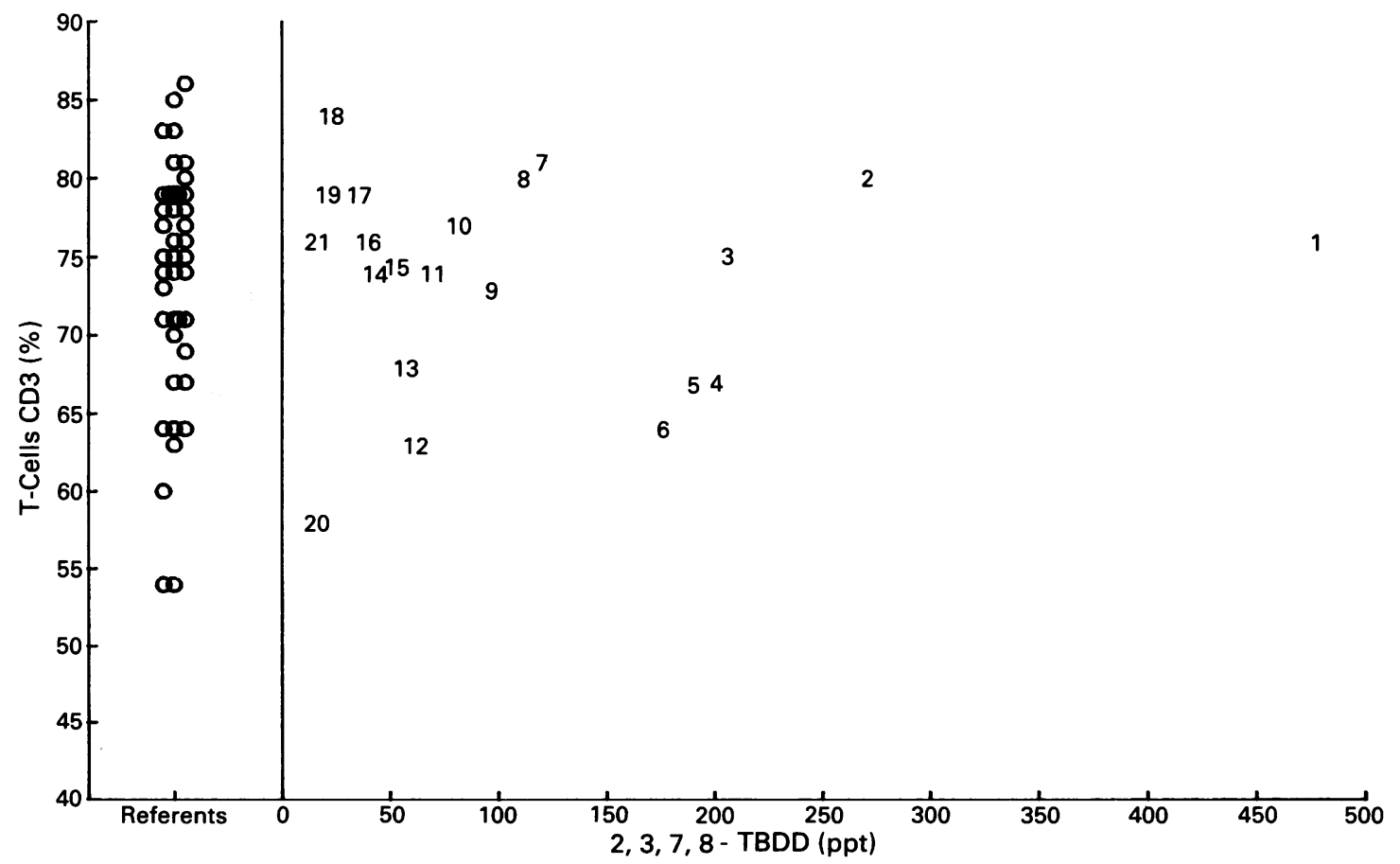

Figure $3 T$-cells CD3 (\%) $v$ 2,3,7,8-TBDD (ppt) based on the fat content of blood of 21 exposed persons with combined 2,3,7,8-TBDF and 2,3,7,8-TBDD concentrations above 20 ppt. 


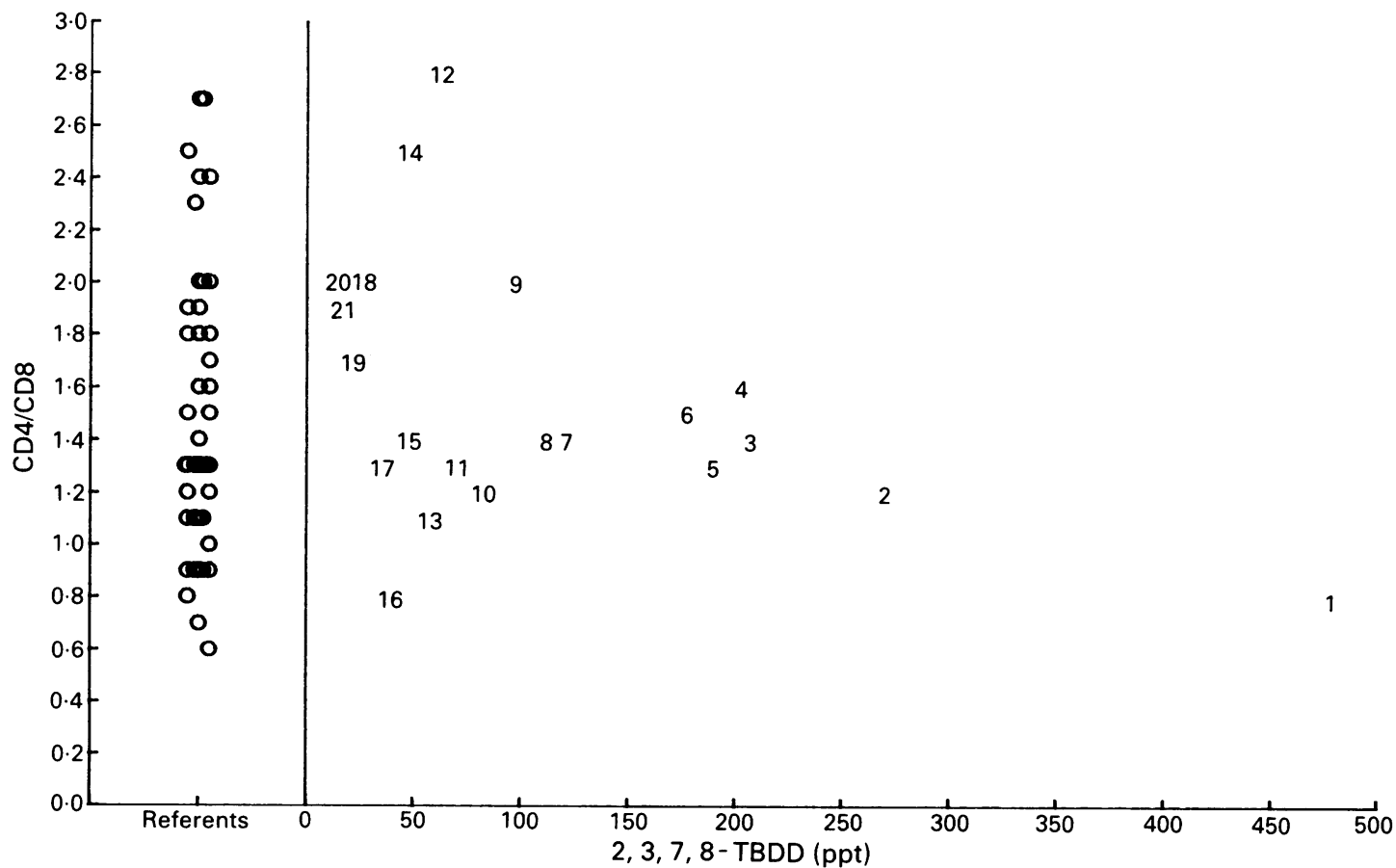

Figure $4 C D 4 / C D 8$ ratio $v$ 2,3,7,8-TBDD (ppt) based on the fat content of blood of 21 exposed persons with combined $2,3,7,8-T B D F$ and 2,3,7,8-TBDD concentrations above 20 ppt.

concentrations above $20 \mathrm{ppt}$ and for the $\mathbf{4 2}$ referents. The two groups were comparable in age, smoking, alcohol intake, and body mass index. Smoking was somewhat more common in the exposed group with an average consumption of $\mathbf{1 4 . 4}$ cigarettes a day compared with 11.5 cigarettes a day among the referents. Comparisons of mean values of the various measures produced statistical differences at the 0.05 level for only one parameter, IgM. The mean IgM concentration was $142.0 \mathrm{mg} / \mathrm{dl}$ in the exposed and $114.7 \mathrm{mg} / \mathrm{dl}$ in the referent group. All individual results in the exposed group were within the reference range of $60-250 \mathrm{mg} / \mathrm{dl}$. Three subjects in the referent group, however, had IgM values below the lower reference limit. The standard deviation for circulating immune complexes was higher in the referent than the exposed group. This was largely due to one clinically healthy individual with a high reading of $106.4 \mu \mathrm{g} / \mathrm{ml}$ in the referent group.

Scatter plots of the immune system parameters were made. None of these was strongly suggestive of an effect of exposure. Figures 2-9 show examples (lymphocytes, T-cells, $\mathrm{CD} 4 / \mathrm{CD} 8$ ratio, $\mathrm{CD} 4$ CDW29, NK-cells, B-cells, $\gamma$-globulin, and complement C4). Also, linear regression analyses were performed to further evaluate each parameter of the immune system in relation to both exposure measures (2,3,7,8-TBDF and 2,3,7,8-TBDD) and other factors (age, smoking, alcohol intake, and body mass index). These results utilised all 84 observations and are summarized in table 3. At least one significant association at the 0.01 level was found for each independent variable. Amount of cigarette smoking was positively associated with increased counts of total lymphocytes, T-cells, T-helper cells, and B-cells and was negatively associated with $\gamma$ globulin and IgG concentrations. Age was positively associated with per cent $\mathrm{T}$-helper inducer cells, IgA and with complement $\mathrm{C} 4$ concentrations. The only parameter significantly associated with an exposure measure at the 0.01 level was complement $\mathrm{C} 4$, which was positively related to both $2,3,7,8-\mathrm{TBDF}$ and $2,3,7,8-T B D D$ concentrations. This association was highly dependent on one observation (see fig 9), that being the subject with the highest internal exposure dose. With this person removed, the direction of the association with 2,3,7,8-TBDD remains positive but with a $p$ value of only $0 \cdot 28$. Marginal associations were seen for per cent lymphocytes (decreased with 2,3,7,8-TBDD, $p=0.054$ ), total lymphocyte count (decreased with 2,3,7,8-TBDF, $\mathrm{p}=0.056$ ), $\mathrm{T}$-cell count (decreased with 2,3,7,8-TBDF, $p=0.045$ ), T-helper cell count (decreased with 2,3,7,8-TBDF, $p=0.045$ ), and complement C3 (increased with 
Table 3 Summary results with $p<0.01$ from regression of immune system parameters on TBDF and TBDD blood concentrations, age, smoking, alcohol intake, and body mass index

\begin{tabular}{|c|c|c|c|c|c|c|}
\hline & \multicolumn{2}{|c|}{ Exposure associations } & \multicolumn{4}{|c|}{ Covariate associations } \\
\hline & $T B D F$ & $T B D D$ & Age & Smoking & Alcohol & $B M i$ \\
\hline $\begin{array}{l}\text { Lymphocytes }(\mathrm{n} / \mu \mathrm{l}) \\
\text { T-cells CD3 }(\mathrm{n} / \mu \mathrm{l}) \\
\text { T-helper cells CD4 (n/ } / \mu \mathrm{l}) \\
\text { T-helper inducer cells }(\%) \text { CD4CDW29 } \\
\text { B-cells CD19 (n/ } / \mu \mathrm{l}) \\
\gamma \text {-Globulin }(\%) \\
\text { IgA (mg/dl) } \\
\text { IgG (mg/dl) } \\
\text { IgE (IU } / \mathrm{ml}) \\
\text { Complement C3 (mg/dl) } \\
\text { Complement C4 (mg/dl) }\end{array}$ & $\uparrow$ & $\uparrow$ & $\uparrow$ & $\begin{array}{c}\text { nocompeten } \\
\uparrow \\
\uparrow \\
\uparrow \\
\text { oral param } \\
\downarrow \\
\downarrow\end{array}$ & $\uparrow$ & $\uparrow$ \\
\hline
\end{tabular}

$\uparrow$ Positive association; $\downarrow$ negative association.

2,3,7,8-TBDF, $p=0.054$ ). All of these marginal associations with the exception of that for complement C3 were dependent on results for the subject mentioned.

\section{Discussion}

The biomonitoring results from this study substantiate, for the first time, brominated dioxin and furan burdens in workmen assigned to extrusion production of plastic resins containing brominated diphenyl ethers. Although substitute flame retardants were introduced for these materials in 1990, biomonitoring data for new employees entering the unit from 1986-8 suggest that engineering controls implemented during the mid-1980s, had already greatly reduced the potential for employee contact with PBDFs and PBDDs.

Estimation of pharmacokinetic parameters for $2,3,7,8$-TBDD is of interest, in part because of the long half life (seven years) estimated for 2,3,7,8TCDD in humans. ${ }^{8}$ The only other human data for

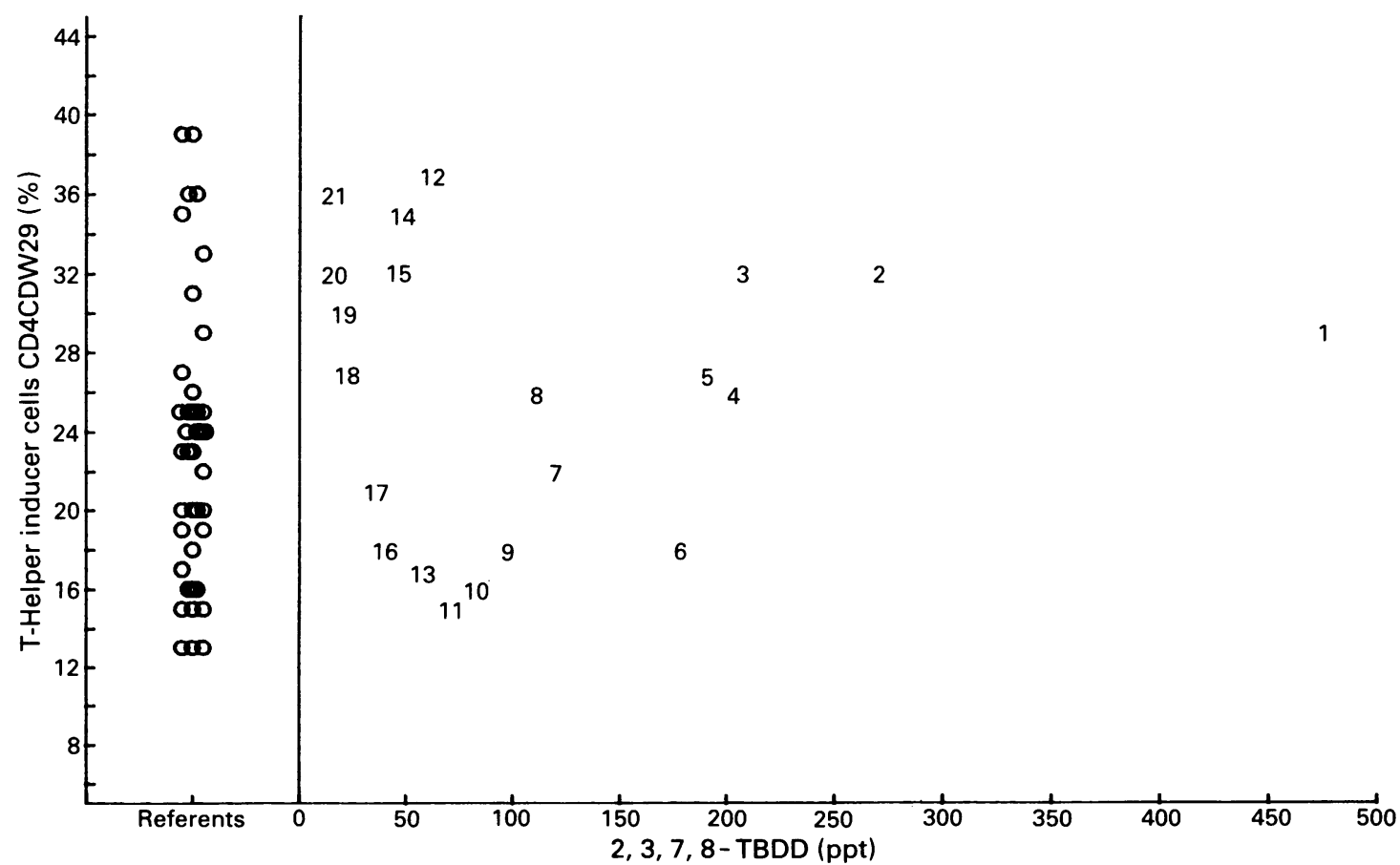

Figure 5 T-helper inducer cells CD4CDW29 (\%) $v 2,3,7,8-T B D D$ (ppt) based on the fat content of blood of 21 exposed persons with combined 2,3,7,8-TBDF and 2,3,7,8-TBDD concentrations above 20 ppt. 


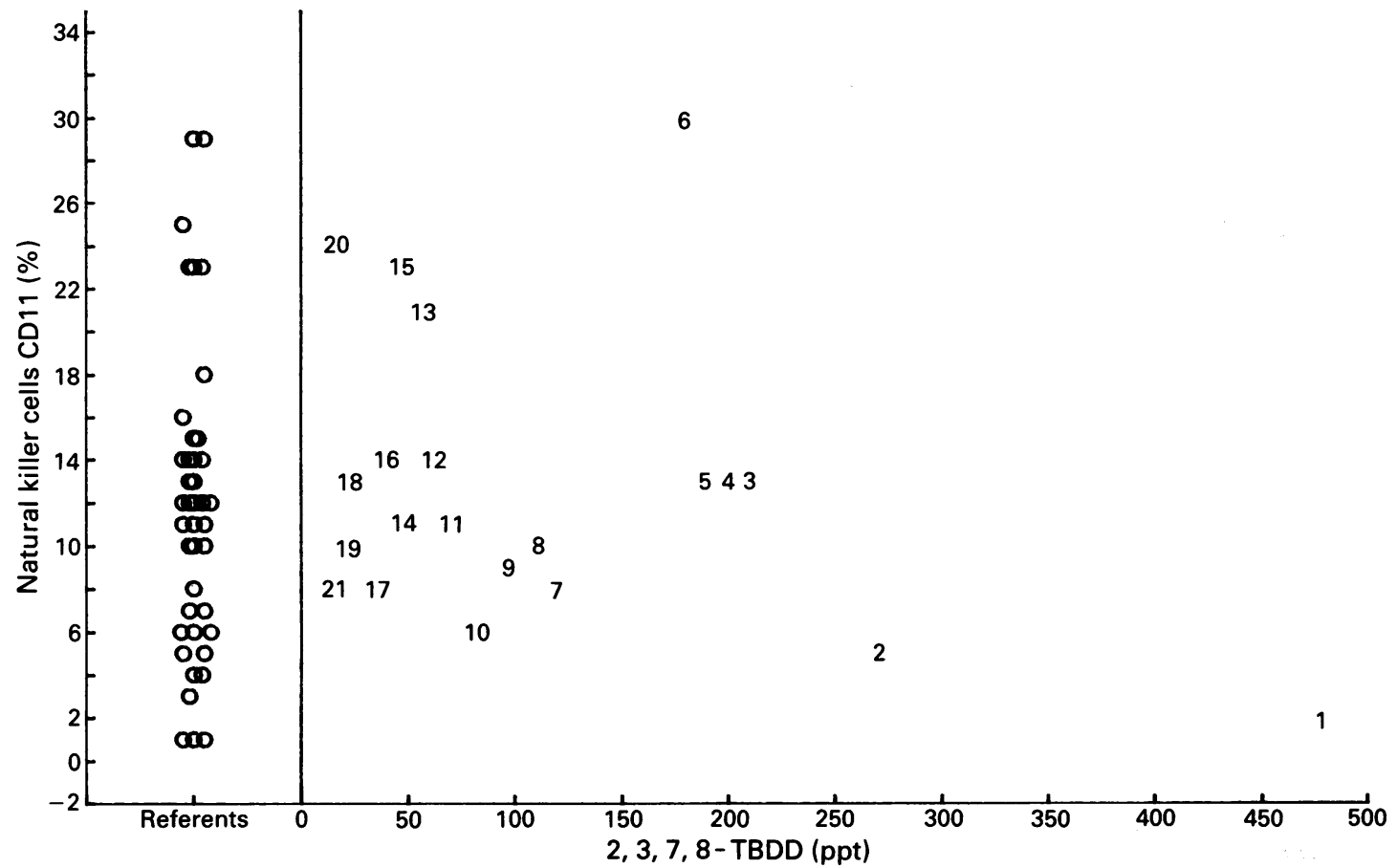

Figure 6 Natural killer cells CD11 (\%) $v$ 2,3,7,8-TBDD (ppt) based on the fat content of blood of 21 exposed persons with combined 2,3,7,8-TBDF and 2,3,7,8-TBDD concentrations above 20 ppt.

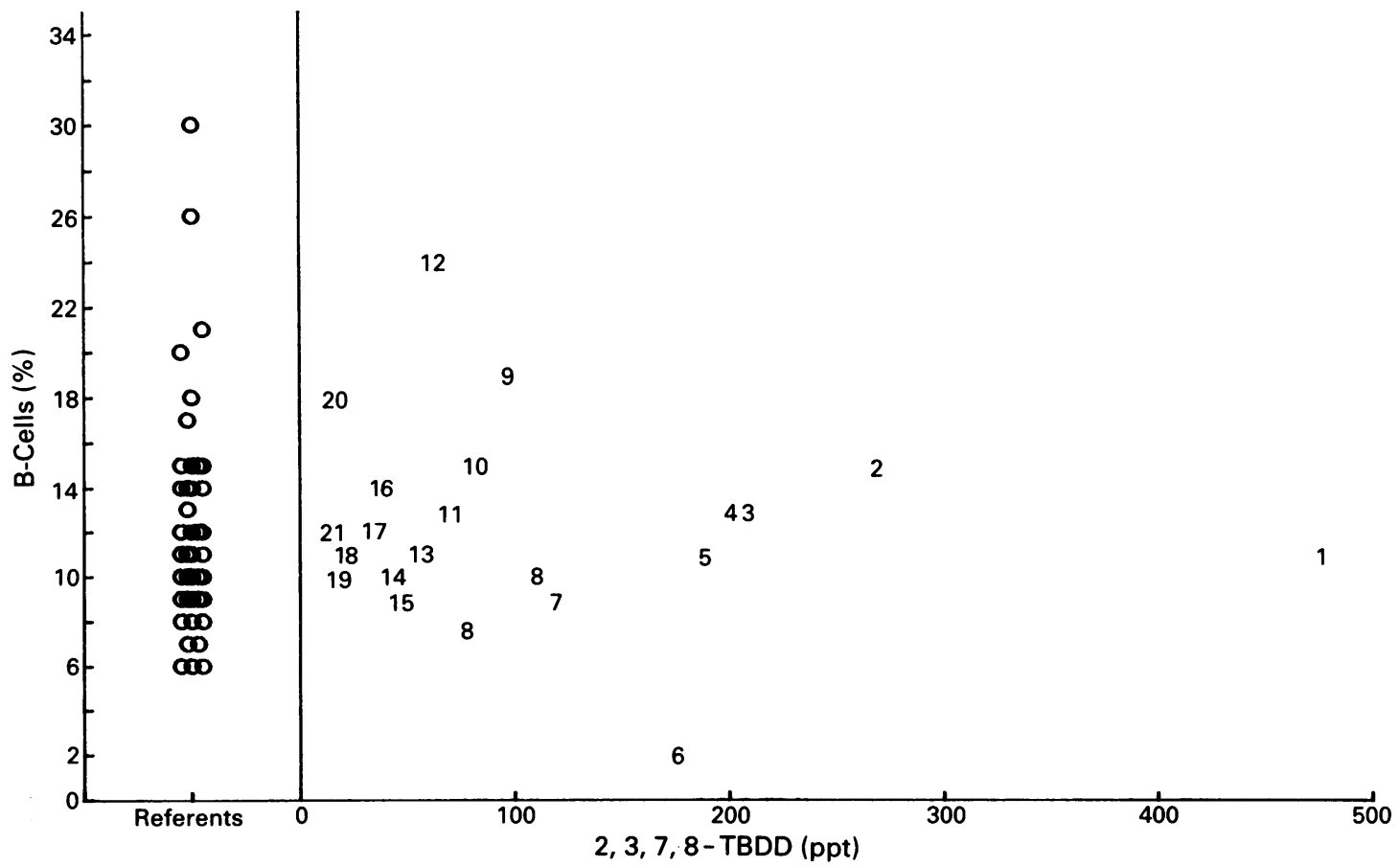

Figure 7 B-cells CD19 (\%) $v 2,3,7,8-T B D D$ (ppt) based on the fat content of blood of 21 exposed persons with combined $2,3,7,8-T B D F$ and 2,3,7,8-TBDD concentrations above 20 ppt. 
Table 4 Summary of biomonitoring data for five subjects 1989-91

\begin{tabular}{clccr}
\hline \multicolumn{2}{l}{ Person } & 1989 & 1990 & 1991 \\
\hline 1 & TBDF (ppt) & 176 & 112 & 77 \\
& TBDD (ppt) & 527 & 478 & 457 \\
3 & TBDF (ppt) & 180 & 58 & 61 \\
& TBDD (ppt) & 357 & 208 & 207 \\
4 & TBDF (ppt) & 139 & 28 & 35 \\
& TBDD (ppt) & 425 & 203 & 285 \\
14 & TBDF (ppt) & 94 & 21 & 20 \\
& TBDD (ppt) & 134 & 48 & 49 \\
18 & TBDF (ppt) & 91 & $<15$ & 22 \\
& TBDD (ppt) & 140 & 23 & 32 \\
\hline
\end{tabular}

2,3,7,8-TBDD that we are aware of are single observations reported for a chemist some 34 years after he had synthesised 2,3,7,8-TBDD in the laboratory. 'A concentration of 2000 ppt 2,3,7,8TBDD in blood was reported. This single observation also suggested a long half life for 2,3,7,8-TBDD. Using biomonitoring samples collected on three separate occasions for five subjects (see table 4), we estimated the biological half life for both $2,3,7,8-$ TBDD and 2,3,7,8-TBDF. A one compartment model and elimination of all exposure sources between the observation points was assumed. The measurements in 1990 and 1991 were carried out at the mass resolution of 10.000 (HRMS) whereas the measurements from 1989 were at the mass resolution of 1.500 (LRMS). Measurements with LRMS could result in higher values than those found with HRMS, particularly for samples containing low dioxin concentrations. For this reason, greater reliability is presumed for the three subjects with initial 2,3,7,8TBDD concentrations above 300 ppt. For these three subjects, our calculations gave half life estimates of from 2.9 to 10.8 years (mean 5.9 years) for $2,3,7,8$-TBDD and from 1.1 to 1.9 years (mean 1.5 years) for $2,3,7,8-T B D F$. Half life estimates were less for the two subjects with lower 2,3,7,8-TBDD concentrations in 1989. Based on these data, the mean biological half life of 2,3,7,8-TBDD appears to be comparable with that of 2,3,7,8-TCDD, although rather high interindividual variability may exist in elimination rates. We will continue to follow up these five persons analytically.

Animal studies indicate that the chlorinated dioxins, and especially 2,3,7,8-TCDD, can cause various immunological effects. ${ }^{10-13}$ It is reasonable to expect, and indeed it has been shown, that similar effects occur with the brominated analogues of chlorinated dioxins. ${ }^{14}$ The immunological effects seen with 2,3,7,8-TCDD include lymphoid involution, especially of the thymus, suppression of both cell mediated immunity and humoral immune response, and suppressed complement activity with possible rebound to above background concentrations in animals exposed to lower doses. More extensive and

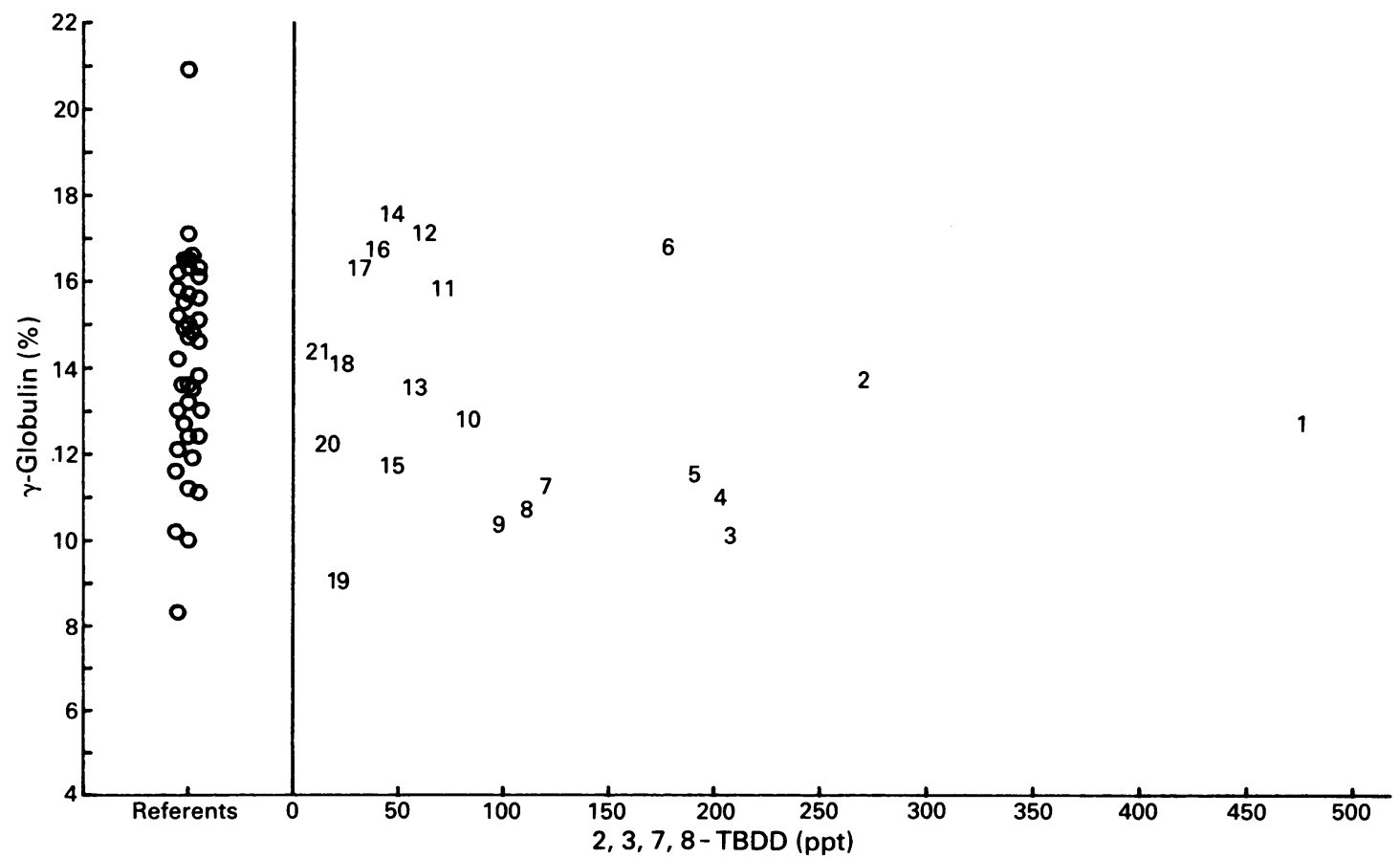

Figure $8 \gamma$-Globulin (\%) $v$ 2,3,7,8-TBDD (ppt) based on the fat content of blood of 21 exposed persons with combined $2,3,7,8-T B D F$ and $2,3,7,8-T B D D$ concentrations above 20 ppt. 


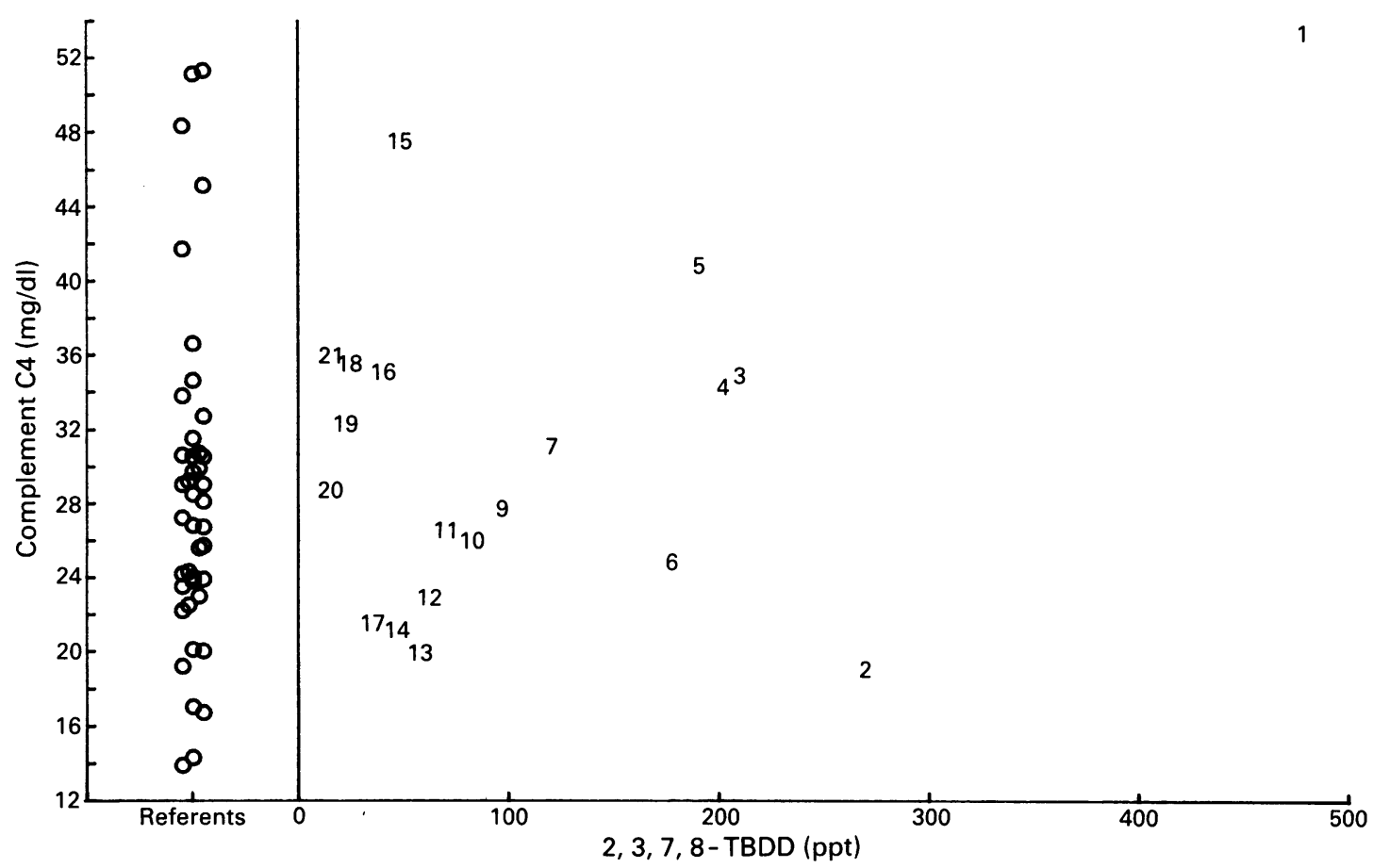

Figure 9 Complement $C 4(\mathrm{mg} / \mathrm{dl})$ v 2,3,7,8-TBDD (ppt) based on the fat content of blood of 21 exposed persons with combined $2,3,7,8-T B D F$ and 2,3,7,8-TBDD concentrations above 20 ppt.

longer lasting effects seen in young animals may be mediated through actions of 2,3,7,8-TCDD on maturational or differential processes as well as on functional processes of immunocompetent cells. ${ }^{12}$ Recently, Neubert et $a l^{1516}$ reported a decrease in the percentage of cells with CD4 + CDW 29 + surface markers after treating a non-human primate (marmoset) with a single subcutaneous dose of $10 \mathrm{ng} 2,3,7,8-\mathrm{TCDD}$ per $\mathrm{kg}$ body weight. These investigators suggested that a count of cells carrying these markers ( $T$ helper-inducer cells) should be considered as one of the parameters of choice for monitoring exposed human populations.

Immunotoxicity information for the chlorinated dioxins is both less complete and less consistent for humans. Among four studies examining immunological endpoints, no consistent abnormalities were identified. ${ }^{17-21}$ Jennings $e t$ al $^{17}$ reported an increase in NK-cells identified by Leu-7, more ANAs using Hep2cells, and increased immune complexes at low titres in 18 workers 17 years after exposure to $2,3,7,8-T C D D$. In a much larger study of persons experiencing presumed environmental exposure to $2,3,7,8-T C D D$, Hoffmann $e t ~ a l^{18}$ initially reported a high anergy rate based on skin testing for delayed hypersensitivity. Upon subsequent follow up, these results were shown to be invalid. ${ }^{19}$ In follow up studies conducted after the Seveso incident, Tognoni and Bonaccorsi ${ }^{21}$ reported raised total complement haemolytic activity in serum from children, with a tendency toward higher serum concentrations in children with chloracne.

The Air Force study of ranch hands is the most extensive immunological study of subjects exposed to chlorinated dioxins in terms of parameters investigated (skin tests, marker studies, immunoglobulins, and functional studies), number of participants (more than 500), and availability of biomonitoring data. ${ }^{20}$ In this study, results of skin tests were not associated with exposure to dioxin, and functional tests indicated, if anything, a positive rather than a depressed response. There was an increase in IgA with higher exposure to dioxin, but no consistent findings linking the distribution of lymphocyte subpopulations to the biomonitoring results.

In the present study, 16 measures of the immune system were examined in relation to exposure state and both concentration of 2,3,7,8-TBDF and 2,3,7,8-TBDD in blood lipids. Many statistical comparisons were made, fully recognising that some spurious findings might be generated through the multiple testing. This was done, however, to ensure that any unusual outcome patterns would be identi- 
fied for further evaluation on a group and individual basis. Our analyses found no statistically significant relations at the 0.01 level between lymphocyte subpopulation counts and $2,3,7,8$-TBDF or $2,3,7,8$ TBDD concentration. In particular, no significant or marginal associations were found between 2,3,7,8TBDD and either counts of NK cells or per cent T helper-inducer cells. Marginal decreases occurred in per cent total lymphocytes, total lymphocyte counts, $\mathrm{T}$-cell count, and $\mathrm{T}$-helper cell count with either $2,3,7,8-\mathrm{TBDF}$, or $2,3,7,8-\mathrm{TBDD}$, or with both. These associations were largely due to the results for one subject whose $2,3,7,8-\mathrm{TBDD}$ concentration was nearly twice that of any other study participant (case 1 in figs 2-9). More clinical details regarding this subject are discussed later.

Also no associations were found between the measures of exposure and either circulating immune complexes or per cent positive ANAs in the present study; both of these parameters had been linked by Jennings et $\mathrm{ll}^{17}$ to past exposures to 2,3,7,8-TCDD.

The positive statistical associations for complement $\mathrm{C} 4$ and marginally for complement C3, appear in agreement with the Seveso findings, but contradict the decreased complement activity reported in mouse studies unless a rebound effect is postulated. ${ }^{1321}$ Unlike the Seveso incident, in which exposures were sufficient to produce cases of chloracne, dermatological examinations of participants in the present study showed no skin lesions consistent with an acnegenic response.

From a clinical point of view, borderline increases in complement concentrations have not been associated with the occurrence of immunodeficiency disease. ${ }^{22}$ The statistical association between exposure and complement $\mathrm{C} 4$ in the present study was largely dependent on results for one person (case 1). This person had the highest PBDF and PBDD concentrations of any participant, the highest complement $\mathrm{C} 4$ concentration $(53.6 \mathrm{mg} / \mathrm{dl})$, and low counts for total lymphocytes, $T$-cells, $T$-helper cells, and NK cells. At the time of examination he was a 54 year old moderate cigarette smoker who had worked as an extruder operator since 1977. His clinical profile included hypertension, low back pain, hyperuricaemia, and signs of an old inactive tuberculosis identified on chest $x$ ray films. None of the above conditions have been associated with exposure to dioxin. Based on a review of his past clinic records as well as current examination results, there were no clinical indications of immunodeficiency disease (see addendum). In general, there were no differences in the prevalence of acute or chronic infectious diseases or other allergic or autoimmune disorders between the study group and referents based on diagnostic results reported by the examining physicians.

Our findings on covariate determinants of parameters of the immune system are generally
. consistent with the findings reported by others. ${ }^{23}$ Specifically, in reference to cigarette smoking, we found significant increases in absolute cell counts for several lymphocyte subpopulations (total lymphocytes, T-cells, T-helper cells and B-cells) and decreases in $\gamma$-globulin and IgG concentrations.

To summarise, a relatively high concentration of complement $\mathrm{C} 4$ and low total lymphocyte, T-cell, T-helper cell, and NK cell counts, but no clinical evidence of immunodeficiency disease, were seen in one employee with a blood lipid concentration of 478 ppt 2,3,7,8-TBDD (but see addendum). For the other participants, who had been exposed for up to 13 years to brominated dioxins and furans and whose current blood lipid concentrations of 2,3,7,8-TBDD were as high as several hundred ppt, there were no notable effects on the distribution of cells of the immune system or on other immunological parameters. These findings do not exclude the possibility of functional abnormalities of the immune system that were not investigated. Nevertheless, it appears unlikely that the functional state of these employees has been compromised because no differences between the study and referent groups in the prevalence of infectious or other diseases related to immune state were identified based on findings at medical examination.

We thank Professor S Meuer of the Division of Applied Immunology, German Cancer Research Center, Heidelberg for his critical review and discussion of the immunological results.

1 Brenner KS, Knies H. Formation of polybrominated PBDFs and PBDDs during extrusion production of a polybutyleneterephthalate (PBTP)/glassfibre resin blended with decabromodiphenylether (DBDPE)/ $\mathrm{Sb}_{2} \mathrm{O}_{3}$; product and workplace analysis. Bayreuth: Proc Dioxin' 90 1990;2;319-24.

2 Pohle H. Polybromierte Diphenylether-Verbot als Flammschutzmittel. Z Umweltchem Okotox 1990;2:148-50.

3 Päpke O, Ball M, Lis ZA, et al. PCDD/PCDF in whole blood samples of unexposed persons. Chemosphere 1989;19:941-8.

4 Cramer HP, Ayling RE, Thornburg KR, et al. Evaluation of an analytical method for the determination of polybrominated dibenzo-p-dioxins/dibenzofurans (PBDD/PBDF) in human adipose. Chemosphere 1990;20:821-7.

5 Neubert D, Golor G, Hagenmaier H. Toxic TCDDequivalents: problems and applicability for risk assessment. In: Health effects and safety assessment of dioxins and furans. Proceedings of the toxicology forum, Karlsruhe, Germany, January 15-17, 1990:560-74.

6 Safe S. Development of TEFs for halogenated aromatic hydrocarbons. Bayreuth: Proc Dioxin' 90 1990;1:329-31.

7 Giovannucci E, Colditz G, Stampfer MJ, et al. The assessment of alcohol consumption by a simple self-administered questionnaire. Am J Epidemiol 1991;133:810-7.

8 Pirkle JL, Wolfe WH, Patterson DG, et al. Estimates of the halflife of 2,3,7,8-tetrachlorodibenzo-p-dioxin in Vietnam veterans of Operation Ranch Hand. $J$ Toxicol Environ Health 1989;27:165-71.

9 Schecter A, Ryan JJ. Chlorinated and brominated dioxin levels in the blood of a chemist who became ill after synthesizing 2,3,7,8-TCDD and 2,3,7,8-TBDD. Bayreuth: Proc Dioxin'90 $1990 ; 4: 141-4$.

10 Vos JG, Luster MI. Immune alterations. In: Kimbrough RD and Jensen AA, eds. Halogenated biphenyls, terphenyls, naphtalenes, dibenzodioxins and related products. Amsterdam: Elsevier, 1989:295-322. 
11 Vos.JG, van Loveren H, Schnurman HJ. Immunotoxicity of dioxin: an overview. Bayreuth: Proc Dioxin'90 1990;1:215-9.

12 Holsapple MP, Morris DL, Wood SC, et al. 2,3,7,8-TCDD induced changes in immunocompetence: possible mechanisms. Annu Rev Pharmacol Toxicol 1991;31:73-100.

13 White KL, Lysy HH, McCay A, Anderson AC. Modulation of serum complement levels following exposure to polychlorinated dibenzo-p-dioxins. Toxicol Appl Pharmacol 1986; 84:209-19.

14 Mason G, Zacharewski T, Denomme MA, Safe F, Safe S. Polybrominated dibenzo-p-dioxins and related compounds: quantitative in vivo and in vitro structure-activity relationships. Toxicology 1987;44:245-55.

15 Neubert R, Jacob-Müller U, Stahlmann R, et al. Polyhalogenated dibenzo-p-dioxins and dibenzofurans and the immune system I. Arch Toxicol 1990;64:345-59.

16 Neubert R, Jacob-Müller U, Helge H, et al. Polyhalogenated dibenzo-p-dioxins and dibenzofurans and the immune system 2. Arch Toxicol 1991;65:213-9.

17 Jennings AM, Wild G, Ward JD, et al. Immunological abnormalities 17 years after accidental exposure to $2,3,7,8$ tetrachlorodibenzo-p-dioxin. $\mathrm{Br} J$ Ind Med 1988;45:701-4.

18 Hoffmann RE, Stehr-Green PA, Webb KB, et al. Health effects of

\section{Addendum}

Retesting of case 1 in September 1991 showed a decrease of complement C4 concentration to $45 \cdot 7 \mathrm{mg} / \mathrm{dl}$. The total lymphocyte count increased from $920 / \mu \mathrm{l}$ to $1700 / \mu \mathrm{l}(18 \mathrm{rel} \%$ to $20 \mathrm{rel} \%)$. Similar increases occurred for T-cells from $700 / \mu \mathrm{l}$ to $1410 / \mu \mathrm{l}$ (76 rel $\%$ to 83 rel \%), T-helper cells from $330 / \mu$ l to $476 / \mu \mathrm{l}$ ( $28 \mathrm{rel} \%$ to $36 \mathrm{rel} \%)$, and NK-cells from $20 / \mu \mathrm{l}$ to $170 / \mu \mathrm{l}$ ( 2 rel $\%$ to $10 \mathrm{rel} \%$ ). Again his major complaints were related to joints and spine. long-term exposure to 2,3,7,8-tetrachlorodibenzo-p-dioxin. JAMA 1986;255:2031-8.

19 Evans RG, Webb KB, Knutsen AP, et al. A medical follow-up of the health effects of long-term exposure to 2,3,7,8-tetrachlorodibenzo-p-dioxin. Arch Environ Health 1988;43:273-8.

20 Wolfe WH, Michalek JE, Miner JC, et al. Air Force Health Study. An epidemiologic investigation of health effects in Air Force personnel following exposure to herbicides. Volume VI. Serum dioxin analysis of 1987 examination results. Brooks Air Force Base, Texas: USAF School of Aerospace Medicine, Human Systems Division (AFSC), 1991. (NTIS: AS A222 573).

21 Tognoni G, Bonaccorsi A. Epidemiological problems with TCDD. A critical review. Drug Metab Rev 1982;13:447-69.

22 Morgan PB, Walpot MJ. Complement deficiency and disease. Immunol Today 1991;12:301-6.

23 Mili F, Flanders WD, Boring JR, Annest JL, Destefano F. The associations of race, cigarette smoking, and smoking cessation to measures of the immune system in middle-aged men. Clin Immunol Immunopathol 1991;59:187-200.

Accepted 11 November 1991. 